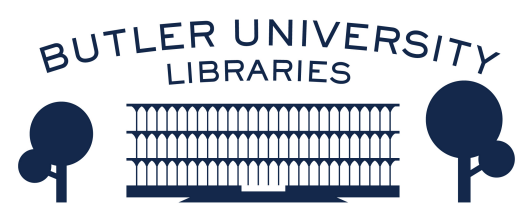

Journal of Hindu-Christian Studies

Volume 8

Article 13

January 1995

\title{
Book Review: "Women of Power and Grace: Nine Astonishing, Inspiring Luminaries of our Time"
}

Heather Botting

Follow this and additional works at: https://digitalcommons.butler.edu/jhcs

Part of the Religion Commons

\section{Recommended Citation}

Botting, Heather (1995) "Book Review: "Women of Power and Grace: Nine Astonishing, Inspiring Luminaries of our Time"," Journal of Hindu-Christian Studies: Vol. 8, Article 13.

Available at: https://doi.org/10.7825/2164-6279.1118

The Journal of Hindu-Christian Studies is a publication of the Society for Hindu-Christian Studies. The digital version is made available by Digital Commons @ Butler University. For questions about the Journal or the Society, please contact cbauman@butler.edu. For more information about Digital Commons @ Butler University, please contact digitalscholarship@butler.edu. 
his publisher had allowed him to include more. Also, it is not clear exactly what the result of this "mutual transformation" of the concepts "Christ" and "guru" will be. If we truly accustom ourselves to thinking of Jesus as guru, it begins to sound odd to hear of God's "raising Jesus from the dead and appointing him guru for all" (p.103). The very intimacy and local appeal of the guru seems to be undone by requiring that he be the guru "for all". Thangaraj is aware of this, and has in mind a process of mutual critique in which neither concept will remain unchanged. We are given some brief indications of where this will lead: away from traditional Śaiva Siddhānta metaphysics, for example, as well as away from traditional Christian exclusivism and "christolatry". His suggestions are brief and tentative, appropriate perhaps to an initial "experiment". One hopes that Thangaraj will continue his experiment, exploring his richly suggestive if somewhat vague image of Jesus as "crucified guru", and elaborating its implications for both Christians and Hindus in more detail.

David Carpenter

St Joseph's University, Philadelphia

\section{Women of Power and Grace: Nine Astonishing, Inspiring} Luminaries of our Time. Timothy Conway. Santa Barbara, California: The Wake Up Press, 1994. 351 pp.

TIMOTHY CONWAY PRESENTS the tales and teachings of nine women of various faiths whom he describes as "illustrious spiritual leaders" and "profound exemplars of holiness". Conway commences each of his decidedly uncritical examinations of the lives and letters of these women with a short biography, followed in most cases with a digest of quotable quotes.

He starts, appropriately enough, with America's first official saint, Mother Frances Cabrini, whose accomplishments at the turn of the century included a drive for much-needed schools, orphanages, hospitals, social service programs, and convents. Unfortunately he sets a schmaltzy tone that he never shakes throughout the book, the style being a strange blend of obsequiousness and condescension.

This is certainly not an academic study but rather a sentimental review in which Conway makes the perilous assumption that he is preaching to the converted. $\mathrm{He}$ alienates the objective reader in an apparent attempt to appease the disciples of the various women he seeks to exalt. The tales take on the air of folklore and fable. For example, Conway makes the unqualified assertion that the Roman Catholic nun Therese Neumann of Germany ate and drank nothing but a daily Eucharist wafer for 40 years and in the process doubled her weight to over 215 pounds!

Conway describes an Eastern Orthodox "holy fool", Pelagia, who cured people with a witch-like cackle, and Russian Orthodox emigrée to France, Maria Skobtsova, who saved hundreds of lives before herself becoming a casualty in a Nazi death camp. The Muslim Sufi saint Hazrat Babajan fled her native Afghanistan to make her home under a neem tree at Poona, India, where she is credited with healing the sick and the afflicted, and once used her talents at clairvoyance to save lives when fire broke out in a crowded theatre miles away.

But Conway has a particular soft spot for the four Hindu holy women to whom he devotes fully half his book. The Hindu "Guru of gurus", Āndandamayi Mā, had the capacity to dematerialize at will and the ability to carry out spiritual 
"empowerment", as attested to by the author himself "from a number of very potent and unsought dreams of Mā with which she blessed him, though he had never even met her". Similar gifts are claimed for Śyāma Mātāji and Amma Mātā Amritānandamayi. He seems particularly impressed with Anasūyā Devī, who died in 1985. Little is known of her in the West, Conway says, but "since Amma's return to Formless Light, her Divine Motherly Presence is still profoundly experienced".

The disciples of each of the remarkable women described here will find in the book fodder to reaffirm their faith. Other readers may find the anecdotes and quotations of passing interest from the standpoint of comparative religion. But Conway's uncritical tone and florid language are stylistically irritating. His personal affirmations of faith seem insincere at times and, contrary to his intention, invite a healthy scepticism.

Heather Botting University of Victoria

\section{Monastic Life in the Christian and Hindu Traditions: A Compara-} tive Study. Austin B. Creel and Vasudha Narayanan (Eds.). Lewiston, N.Y.: Edwin Mellen Press, 1990, xiii +593pp.

RESULTING FROM A research conference held at the University of Florida in 1985 , this volume is the first attempt by a team of scholars who are specialists on monasticism to offer a comparative HinduChristian study of the topic. The editors wisely claim that it is but an introductory study and Juergensmeyer in his concluding chapter points out that rather than being comparative, most of the volume's essays are studies of specific aspects of monastic life in either Hindu or Christian case studies - with the reader left to do the comparative analysis. While this may frustrate some readers, it has the advantage of avoiding facile comparisons and ensuring that the studies included do offer in-depth presentations of various aspects of Hindu and Christian monasticism. Juergensmeyer's conclusion, "The Monastic Syndrome", offers a helpful comparative analysis of the essays so that the comparative study promised in the title is not left entirely to the reader to construct. While some of the authors (e.g. Elder, Linge, and Cousins) do make reference to the comparative task at hand, many authors give the announced unifying thread of the volume (The
Comparative Study of Hindu and Christian Monastic Life) little mention, and this is my major criticism of the book. Also, T. N. Madan's chapter on the Pandits of Kashmir focuses on their solid commitment to the householder rather than monastic life, which they deny. Consequently, this essay does not fit the theme of the volume and should have been excluded by the editors. Aside from these critical comments, I found much of value in the book.

If the reader is interested in the comparative study of monastic life, I recommend that one begin by reading Juergensmeyer's fine concluding overview and comparative analysis of the essays included. Then one will be in a better position to approach the individual case studies and do the comparative exercise for oneself. Juergensmeyer convincingly proposes that one can find a common pattern of monastic behaviour across Christianity and Hinduism which he summarizes as "a religious calling to undertake an intense personal spiritual activity that separates those involved in it from ordinary society and binds them together in same-sex kindred fellowships that provide ideal alternatives to 